JOSING: Journal of Nursing and Health

Volume 2, Nomor 1, Desember 2021

e-ISSN: 2745-7877

p-ISSN: 2746-0851

DOI: https://doi.org/10.31539/josing.v2i1.2976

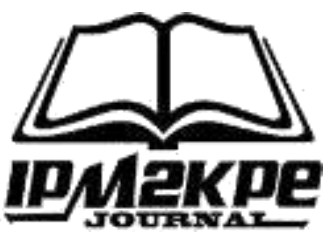

\title{
RELIGIOUS PRACTICES ON HIV/AIDS PATIENTS
}

\author{
Muhammad Bagus Andrianto ${ }^{1}$, Padila $^{2}$, Juli Andri $^{3}$, Andry Sartika $^{4}$ \\ Harsismanto, $\mathrm{J}^{5}$ \\ University of Muhammadiyah Bengkulu ${ }^{1,2,3,4}$ \\ Pematang Tiga Health Center ${ }^{5}$ \\ bagus@umb.ac.id ${ }^{1}$
}

\begin{abstract}
This study aims to determine the relationship between religious practices of people living with HIV/AIDS. The design in this study is a descriptive-analytic study. The survey results from 153 respondents that most of the religious practices of Islam in the HIV/AIDS group were moderate 105 (68.6\%). In conclusion, there is a significant relationship between the level of spiritual practice of people living with HIV/AIDS.
\end{abstract}

Keywords: HIV/AIDS, Religious Practice

\section{INTRODUCTION}

Human Immunodeficiency Virus (HIV) is an infectious disease that is the leading cause of death with high mortality (mortality) and disease incidence (morbidity) and requires a reasonably long diagnosis and therapy (Padila, 2012). HIV is a virus that attacks white blood cells (lymphocytes) in the body which results in a decrease in human immunity, causing Acquired Immunodeficiency Syndrome (AIDS) (Ministry of Health RI, 2017).

Human immunodeficiency viruses are the two lentivirus species that cause AIDS. This virus attacks humans and attacks the immune system, so the body becomes weak in fighting infection. If this virus continues to attack the body, our body's defense system will get weaker (Armiyati et al., 2015).

According to WHO, HIV has become a major global health problem. So far, HIV has claimed more than 34 million lives. In 2014 there were 1.2 million people died from contracting HIV/AIDS. By the end of 2014, around 36.9 million people were living with HIV; Sub-Saharan Africa was the most affected region. Namely, in 201425.8 million people were living with HIV, and Africa accounted for almost $70 \%$ of the global HIV infections. (WHO, 2015).

While in Indonesia, the cumulative number of people living with HIV/AIDS aged $>15$ years in 2015 for the number of new HIV was 30,935 people, in 2016 there were 41,250 people, in 2017, there were 48,300 people. While new cases of AIDS in 2015 were 9,215 people, in 2016 , there were 10,146 people; in 2017 , there were 9,280 people, then the total number of people living with HIV/AIDS in 2017 was 628,492 people with 46,357 new infections and 40,468 deaths (Ministry of Health RI, 2017).

AIDS can attack anyone and if they are positive for infection, these sufferers will become people who transmit the virus for the rest of their lives (Padila, 2012). The severity of the problems experienced by HIV/AIDS patients affects the psychological, social, and spiritual aspects. Patients can experience financial issues, prolonged grief, frustration, guilt, depression, and fear of death. People infected with HIV experience 
various kinds of losses such as loss of health, friends, social status, income, and planned life expectancy (French, 2015).

Stigma and discrimination against PLWHA will be stressful for sufferers. Stress has an unfavorable impact on the health of people with HIV/AIDS, in an effort to deal with stress, an individual needs appropriate stress coping (Indriani \& Fauziah, 2017).

Society often gives negative assumptions to PLWHA patients so that the negative stigma will affect PLWHA in responding to their physiological adaptations (Andri et al., 2020). Research conducted by Maharani (2018) shows that society gives a negative label to PLWHA, so that the negative title causes discrimination in society, such as exclusion, rejection, and avoidance. HIV/AIDS patients can also experience spiritual problems, including blaming God, refusing to worship, worshiping not according to regulations, disturbances in worship, and spiritual distress (Tanjung \& Tumanggor, 2016).

Based on research by Armiyati et al., (2015) in the community of people with HIV/AIDS (PLWHA) in Semarang with a total of 9 respondents, it was found that HIV/AIDS patients experience psychological problems; the findings in this study indicate that when diagnosed with HIV/AIDS for the first time all of them feeling shocked, afraid, angry, irritated, embarrassed, sad and not confident.

Patients with positive religious coping in improving the spirituality of HIV/AIDS sufferers can make a person socialize, psychologically better and the disease progress to be slow. Meanwhile, patients with negative religious coping can lead to a rejection attitude towards ARV therapy, deep feelings of punishment from God and aberrations of adolescent identity (Hulu \& Siregar, 2018).

Factors that influence spirituality include cultural context, family, developmental level, and health status - the influence of family and environment influence in assessing spirituality beliefs. Health status can also have an impact on spiritual beliefs and vice versa. For example, when seriously ill, many people turn to religion for support. In some cases, a person's belief system may influence treatment.

\section{RESEARCH METHOD}

The study was conducted by analytical observation with a cross-sectional approach. The sampling technique was consecutive sampling; all subjects who came and met the selection criteria were included in the study until the number of issues required was completed. The sample in this study amounted to 153 people from a total population of 200 people.

\section{RESULTS}

Table. 1

Distribution of Respondents Characteristics by Age, Gender, Education Level, Occupation and Income $(\mathrm{n}=153)$

\begin{tabular}{lcc}
\hline Characteristics & Frequency & Percentage $(\%)$ \\
\hline Age & & \\
$17-25$ & 28 & 18.3 \\
$26-35$ & 48 & 31.4 \\
$36-45$ & 58 & 37.9 \\
$46-55$ & 19 & 12.4 \\
\hline
\end{tabular}




\begin{tabular}{lcc}
\hline Gender & 72 & \\
Men & 81 & 47.1 \\
Woman & 52.9 \\
\hline Level & 54 & 3.3 \\
Non-School Education & 39 & 15.7 \\
Primary school & 69 & 25.5 \\
Junior high school & 8 & 45.1 \\
Senior High School & 8 & 5.2 \\
D3 & & 5.2 \\
Bachelor degree & 35 & \\
Profession & 7 & 22.9 \\
Does not work & 84 & 4.6 \\
Farmer & 27 & 54.9 \\
Private & & 17.6 \\
Other & 116 & 75.8 \\
Income & 37 & 24.2 \\
< Rp. 1.500.000. & & \\
Rpp.1.500.000. &
\end{tabular}

Based on table 1 shows that of 153 respondents with HIV/AIDS, most of the respondents were women, 81 people $(52.9 \%)$, most of them were between 36-45 years old, 58 people $(37.9 \%)$, with a high school graduate education level of 69 people. (45.1\%), while the respondent's occupation is a private sector by 84 people $(54.9 \%)$, related to the respondent's monthly income of less than $<\operatorname{Rp} 1,500,000,-$ by 116 people $(75.8 \%)$.

Table. 2

Frequency Distribution

Islamic Religious Practice Activities ( $\mathrm{n}=153)$

\begin{tabular}{lcc}
\hline Islamic Religious Practices & Frequency & Percentage (\%) \\
\hline Low Islamic Religious Practices & 28 & 18.3 \\
Moderate Islamic Religious Practices & 105 & 58.6 \\
High Islamic Religious Practices & 20 & 13.1 \\
Total & 153 & 100 \\
\hline
\end{tabular}

Table 2 shows that from 153 respondents, most of the religious practices of Islam in the HIV/AIDS group are moderate 105 (58.6\%).

\section{DISCUSSION}

The results showed moderate relationships between people living with HIV/AIDS and Islamic religious practices. Quite a lot of religious coping followed her. Religiosity can affect a person's attitude, behavior, thinking, and appearance. One of the dimensions of religiosity that regulates individuals in behavior and formation is the experience or moral dimension. Morals function to know the boundaries between good and evil and put something in its place, namely, in the actual proportion. Islamic religiosity is not only a religion that instructs its adherents to carry out rituals to worship God, but a true religion has complete teachings that regulate aspects of human life, both parts of worship, social, legal, political, economic, and human morals to achieve happiness in the world and the hereafter. 
One aspect of Islamic religiosity is the dimension of belief in the book of Allah, namely the Qur'an. Muslims are limited to believing in the truth of the Koran as a revelation from God but how to think and understand the content and content of the verses in it. For example, one of the morals of Islam is compassion, which includes forgiveness and Ihsan. Compassion is not only empathy but is a manifestation of external behavior that will appear in the soul. Examples are to forgive the wrong person, to dismiss the bad person.

Religiosity shapes a person's personality in honesty, empathy, tolerance, compassion, enthusiasm. Religious practice is included in the dimension of religiosity, which teaches about morals and faith. The research on spiritual practice shows that it can be concluded that religion is the most needed need for people living with HIV/AIDS. Religion for people living with HIV/AIDS can be a belief to communicate with the creator to ask for forgiveness and help. With these religious beliefs, they can relieve inner conflicts and find peace (Andrianto et al., 2020).

Spirituality is an expression of the meaning and purpose of life, which manifests the deepest self. Humans express spirituality through their unique ability to think, contemplate, and explore the meaning and purpose of life (Yoost \& Crawford, 2016). Spiritual needs are interrelated between relationships with God, relationships with intrapersonal and interpersonal relationships. According to Prasojo's research (2017) which states that the role of spirituality is to get closer to God, appreciate life after an HIV/AIDS diagnosis, need support from the closest people, and have hope for a better life in the future and the results of research conducted by Sugiyanto et al., (2018) which discusses family support in the form of emotional and spiritual, how to get closer to God and hope for life.

Getting closer to God can be done in various ways; praying, reading the scriptures, contemplating the blessings in life, and surrendering to the Almighty are good ways to increase spiritually (Mubarak et al., 2015). According to research conducted by Dalmida et al., (2015) most of the samples attended regular religious services and prayed. This is similar to the results of a study by Arrey et al., (2016), which states that prayer, meditation, regular church services, and religious activities are the primary spiritual/religious sources to achieve connectedness with God. The form of spiritual practice carried out by HIV/AIDS patients is one of the strengths in dealing with the problems they are experiencing.

PLWHA tend to evaluate themselves negatively and feel inferior to others. This is because there is a negative stigma in the community towards PLWHA. This causes low self-esteem, which occurs due to feelings of guilt, loss of positive body image, loss of roles, loss of work, and loss of social networks (Pramesti \& Nuryani, 2016; Saefulloh et al., 2017).

When a person seeks control through his own initiative by asking others for help first or looking for other ways. Such action is a form of negative religious coping in which the way through religious help is used as a last resort, not the main way (Aisyah et al., 2020). In line with research conducted by Amalia et al., (2018), it shows that psychological responses that occur in ODHS patients when tested positive for HIV/AIDS include suicidal ideation, sadness, increased drug use.

The results of research by Baidowi et al., (2020) state that the higher the level of individual spirituality, the better the quality of life possessed by the individual, and vice versa that the better the quality of life of an individual, the higher the level of spirituality had. The strength of one's spirituality can be an essential factor in dealing 
with the changes brought about by illness. Spiritually strong clients will reshape their identity and live to their full potential (Ramadani et al., 2020; Mubarak et al., 2015). People with HIV/AIDS feel that their lives are lacking, so they worry about the future, especially death. If they feel worried about their future, they tend to worship or be closer to God according to their religion (Handayani et al., 2017).

Religion and spirituality become a source of coping for the elderly in dealing with various life problems. The elderly often do worship activities to get peace of mind, enlightenment, and peace (Ekasari et al., 2018).

Researchers found that most people with HIV/AIDS were in adulthood (36-45 years); at that age, the majority realized that their lives had to be closer to God. This is reinforced that spirituality for patients can mean acceptance and submission to God but is accompanied by effort and commitment trying to get healed. One way is to get closer and increase taqwa to Allah. The spiritual need from the religious dimension, which the patient considers very much needed, is through religious practice.

Religious practice is one part of spiritual coping methods with God. Religious coping can help humans reduce anxiety, anxiety, and tension that make them unable to adapt to their environment.38 The coping strategy used in people living with HIV/AIDS in dealing with their illness is religious coping by making a relationship with God, namely making significant changes in their lives. They after suffering from illness. However, people with HIV / AIDS in dealing with their condition do not take the wisdom behind the disease they experience.

\section{CONCLUSION}

Religious practices can be applied to people with HIV/AIDS in dealing with their illness, namely returning to religion to make significant changes in their lives after knowing they suffer from the disease. Health education has only focused on treating the patient's illness, but not on their religion.

\section{SUGGESTIONS}

So psycho religion can be used as an independent nursing intervention to help increase knowledge and overcome psychological problems so that it can help patient care.

\section{REFERENCES}

Aisyah, P. S., Widianti, A. T., \& Lusiani, E. (2020). Koping Religius Remaja ODHA di Kota Bandung. Jurnal Pendidikan Keperawatan Indonesia, 6(1), 37-44. DOI: 10.17509/jpki.v6i1.21111

Amalia, R., Sumartini, S., \& Sulastri, A. (2018). Gambaran Perubahan Psikososial dan Sistem Pendukung pada Orang dengan HIV/AIDS (ODHA) di Rumah Cemara Gegerkalong Bandung. Jurnal Pendidikan Keperawatan Indonesia, 4(1), 77-85. DOI: 10.17509/jpki.v4i1.12346

Andri, J., Ramon, A., Padila, P., Sartika, A., \& Putriana, E. (2020). Pengalaman Pasien ODHA dalam Adaptasi Fisiologis. Journal of Telenursing (JOTING), 2(2), 127141. https://doi.org/10.31539/joting.v2i2.1397

Andrianto, M. B., Setyawati, A. D., Muin, M., \& Mendofa, F. A. M. (2020). Koping Religius pada Kelompok Penderita HIV/AIDS. Journal of Telenursing (Joting), 2(2). 150-157. https://doi.org/10.31539/joting.v2i2.1528 
Armiyati, Y., Rahayu, D. A., \& Aisah, S. (2015). Manajemen Masalah Psikososiospiritual Pasien HIV/AIDS di Kota Semarang. Universitas Muhammadiyah Semarang

Arrey, A. E., Bilsen, J., Lacor, P., \& Deschepper, R. (2016). Spirituality/Religiosity: Acultural and Psychological Resource among Subsaharan African Migrant Women with HIV/AIDS in Belgium. PLoS ONE, 11(7), 1-22. https://doi.org/10.1371/journal.pone.0159488

Baidowi, A. G., Khotima, K., \& Andayani, S. A. (2020). Hubungan Dukungan Sosial dan Spiritual Penderita HIV/AIDS dengan Kualitas Hidup Penderita HIV/AIDS. Jurnal Ilmiah STIKES Citra Delima Bangka Belitung, 3(2), 118- 126. http://jurnalilmiah.stikescitradelima.ac.i d/index.php/JI

Dalmida, S. G., Koenig, H. G., Holstad, M. M., \& Tami, L. (2015). Religious and Psychosocial Covariates of Health Related Quality of Life in People Living with HIV/AIDS. HHS Public Access, 1(1), 1-26. https://doi.org/10.17140/HARTOJ-1101

Ekasari, M. F., Riasmini, N. M., \& Hartini, T. (2018). Kualitas Hidup Lansia: Konsep dan Berbagai strategi Intervensi. Malang: Wineka Media

French, K. (2015). Kesehatan Seksual. Alih Bahasa: Bhetsy Angelina. Jakarta: Bumi Medika

Handayani, F., Sari, F., \& Dewi, T. (2017). Faktor yang Mempengaruhi Kualitas Hidup Orang dengan HIV / AIDS (ODHA) di Kota Kupang. Berita Kedokteran Masyarakat, 33(11), 1049- 1056

Hulu, I. S. A., \& Siregar, A. R (2018). Hubungan Strategi Koping Religius dengan Penyesuaian Diri pada Pasien HIV / AIDS di RSUD Gunungsitoli. Universitas Sumatera Utara. https://repositori.usu.ac.id/handle/123456789/7390\#

Indriani, S. D., \& Fauziah, N. (2017). Karena Hidup Harus Terus Berjalan (Sebuah Studi Fenomenologi Kehidupan Orang dengan HIV/AIDS). Jurnal Empati, 6(1), 385-395 https://ejournal3.undip.ac.id/index.php/empati/article/view/15163

Kementerian Kesehatan RI. (2017). Profil Kesehatan Indonesia Tahun 2017

Maharani, I. (2018). Cap Orang dengan HIV dan AIDS (ODHA) Studi Sosiologi Kualitatif tentang Stigma. Universitas Airlangga. https://repository.unair.ac.id/72470/

Mubarak, W. I., Indrawati, L., \& Susanto, J. (2015). Buku Ajar Ilmu Keperawatan Dasar (2nd ed.). Jakarta: Salemba Medika

Padila, P. (2012). Buku Ajar Keperawatan Medikal Bedah. Yogyakarta: Nuha Medika

Pramesti, D., \& Nuryani, E. (2016). Gambaran harga diri Orang dengan HIV/AIDS (ODHA) di Violet Community Yogyakarta. Sekolah Tinggi Ilmu Kesehatan 'Aisyiyah. https://onesearch.id/Record/IOS3318.INLIS000000000011137

Prasojo, D. (2017). Peran Reliugisitas pada Penderita HIV dan AIDS yang Mengalami Depresi. Jurnal Studia Insania, 5(1), 46. https://doi.org/10.18592/jsi.v5i1.1270

Ramadani, S. P., Hastuti, M. F., \& Yulanda, N. A. (2020). Kebutuhan Spiritual dengan Kualitas Hidup Pasien Hiv/Aids: Literature Review. Jurnal Proners, 5(2), 1-13. https://jurnal.untan.ac.id/index.php/jmkeperawatanFK/article/view/46092

Saefulloh, M., Wayunah, W., \& Husnaniyah, D. (2017). Hubungan Harga Diri dengan Perilaku Seksual pada Penderita HIV AIDS di Kabupaten Indramayu. Jurnal Pendidikan Keperawatan Indonesia, 3(2), 131-138. https://ejournal.upi.edu

Sugiyanto, S., Tarigan, E., \& Kusumaningsih, I. (2018). Pengalaman Spiritualitas Doa Pasien Hiv/Aids di RSUD Sawerigading Palopo dengan Pendekatan Teori Calista Roy. Jurnal Kesehatan Saelmakers Perdana, 1(2), 85-110. 
https://doi.org/10.32524/jksp.v1i2.386

Tanjung, D. M., \& Tumanggor, R. D. (2016). Karakteristik Distress Spiritual pada Orang dengan HIV/AIDS (ODHA) di RSUP Adama Malik Medan. Universitas Sumatera Utara. http://repositori.usu.ac.id/handle/123456789/14653

World Health Organization.(2015). Fact sheet: HIV/AIDS. From www.who.int/mediacentre/factsheets/fs360/en/

Yoost, B. L., \& Crawford, L. R. (2016). Fundamental of Nursing Active Learning FOR Collaborative Practice. Australia: Elsevier 